\title{
How to Transect the Liver? A History Lasting More than a Century
}

\author{
Rocco Scalzone Santiago Lopez-Ben Joan Figueras \\ Hepatobiliary and Pancreatic Surgery Unit, Department of Surgery, Dr. Josep Trueta Hospital, IdlBGi, Girona, Spain
}

\section{Key Words}

Liver transection techniques $\cdot$ CUSA $^{\circledR} \cdot$ Parenchymal

division $\cdot$ Pedicle clamping $\cdot$ Clamp-crush

\begin{abstract}
There is a close relationship between blood loss during transection and unfavorable outcome. Many different methods have been used in order to cut the parenchyma, while leaving vital structures intact, coagulate small vessels and seal small biliary ducts. The first method described was the finger-fracture technique and, alternatively, the clamp-crushing method using a small forceps. With this technique, the liver is crushed between the 'jaws', and the vessels and bile ducts are successively ligated and divided. Technological research using different sources of energy developed the water jet dissectors and the ultrasonic dissectors. The CUSA ${ }^{\circledR}$ has been widely adopted for the fascinating way it could selectively destroy and aspirate parenchyma leaving vascular structures almost intact. Several studies have been addressed to clarify these critical points. However, in the majority of cases they are underpowered to demonstrate clear advantages of one method over the others. In conclusion, the evidence suggested no superiority of other techniques over clamp-crushing. But it must be taken into account that it requires strictly hepatic pedicle clamping. The devices available should be used within the limits of each instrument, as well as the surgical skills of the surgeon. Probably the best option should be a combined approach.
\end{abstract}

Copyright ๑ 2012 S. Karger AG, Basel

\section{KARGER}

Fax +41613061234 E-Mail karger@karger.ch www.karger.com
(C) 2012 S. Karger AG, Base 0253-4886/12/0291-0030\$38.00/0

Accessible online at: www.karger.com/dsu

\section{Introduction}

Liver transection is one of the most important steps during hepatectomy. Many different methods have been put forward in order to reduce excessive bleeding, to shorten postoperative time and to improve outcome. To achieve these objectives, studies have focused on liver macroscopic and microscopic anatomy in these last 50 years. Couinaud's works suggested the importance of liver segmentation and vascular supply, allowing a few years later to turn these bases into practical issues. Microscopic insight gave the input to technological development of new instruments, devices able to selectively divide parenchyma from vessels according to their different mechanical resistance (in which hepatocytes contain less fibrous tissue than the vessel, thus offering less resistance to crushing during parenchymal division).

Currently, many techniques and devices for liver transection are available (table 1), and no consensus on the best method has yet been expressed. The present work discusses the advantages and drawbacks with which the surgeon is faced during parenchymal division.

\section{History}

Hepatic transection remained a challenge for the surgeon for more than a century, beginning from 1888 when Carl Langenbuch performed the first scheduled hepatec-

Joan Figueras, MD, PhD, AFC (hon)

Hepatobiliary and Pancreatic Surgery, Department of Surgery

Dr. Josep Trueta Hospital

ES-17007 Girona (Spain)

Tel. +34972940 256, E-Mail info@jfigueras.net 
Table 1. Comparison of different techniques in liver transection

\begin{tabular}{|c|c|c|c|c|c|}
\hline Reference & Patients & Technique & $\begin{array}{l}\text { Blood loss/ } \\
\text { transfused patients }\end{array}$ & $\begin{array}{l}\text { Operative } \\
\text { time, min }\end{array}$ & $\begin{array}{l}\text { Transection } \\
\text { speed, } \mathrm{cm}^{2} / \mathrm{s}\end{array}$ \\
\hline \multirow[t]{2}{*}{ Takayama et al. [8] } & \multirow{2}{*}{$\begin{array}{l}132 \\
\text { (66 vs. } 66)\end{array}$} & Clamp-crush technique & $452^{\mathrm{a}} / \mathrm{NA}$ & $54^{\mathrm{b}}$ & 1.0 \\
\hline & & Cavitron ultrasonic surgical aspirator & $515^{\mathrm{a}} / \mathrm{NA}$ & $61^{\mathrm{b}}$ & 1.1 \\
\hline \multirow[t]{2}{*}{ Rau et al. [9] } & \multirow[t]{2}{*}{61} & Hydrojet dissector & NA/1.5 & $28^{\mathrm{b}}$ & \multirow[t]{2}{*}{$\mathrm{NA}$} \\
\hline & & Cavitron ultrasonic surgical aspirator & $\mathrm{NA} / 2.5$ & $46^{\mathrm{b}}$ & \\
\hline \multirow[t]{2}{*}{ Koo et al. [22] } & \multirow{2}{*}{$\begin{array}{l}50 \\
(25 \text { vs. } 25)\end{array}$} & Clamp-crush technique & $792^{\mathrm{a}} / \mathrm{NA}$ & 119 & \multirow[t]{2}{*}{ NA } \\
\hline & & Cavitron ultrasonic surgical aspirator & $875^{\mathrm{a}} / \mathrm{NA}$ & 139 & \\
\hline \multirow[t]{4}{*}{ Lesurtel et al. [16] } & \multirow{4}{*}{$\begin{array}{l}100 \\
\text { (4 groups, } \\
25 \text { each) }\end{array}$} & Clamp-crush technique & $1.5^{\mathrm{C} N A}$ & \multirow[t]{4}{*}{ NA } & 3.9 \\
\hline & & Cavitron ultrasonic surgical aspirator & $4^{\mathrm{c}} / \mathrm{NA}$ & & 2.3 \\
\hline & & Hydrojet dissector & $3.5^{\mathrm{c}} / \mathrm{NA}$ & & 2.4 \\
\hline & & Radiofrequency dissecting sealer & $3.4^{\mathrm{c}} / \mathrm{NA}$ & & 2.5 \\
\hline \multirow[t]{2}{*}{ Arita et al. [21] } & \multirow{2}{*}{$\begin{array}{l}80 \\
(40 \text { vs. } 40)\end{array}$} & Clamp-crush technique & $733^{\mathrm{a}} / 0$ & 80 & 0.89 \\
\hline & & Radiofrequency dissecting sealer & $665^{\mathrm{a}} / 2$ & 79 & 0.99 \\
\hline \multirow[t]{2}{*}{ Smyrniotis et al. [20] } & \multirow{2}{*}{$\begin{array}{l}82 \\
\text { (41 vs. } 41)\end{array}$} & Clamp-crush technique & $460^{\mathrm{a}} / 15$ & 211 & \multirow[t]{2}{*}{ NA } \\
\hline & & Sharp transection & $500^{\mathrm{a}} / 13$ & 205 & \\
\hline \multirow[t]{2}{*}{ Lupo et al. [23] } & \multirow{2}{*}{$\begin{array}{l}50 \\
(26 \text { vs. } 24)\end{array}$} & Clamp-crush technique & $\mathrm{NA} / 8$ & 292 & \multirow[t]{2}{*}{ NA } \\
\hline & & Radiofrequency dissecting sealer & $\mathrm{NA} / 13$ & 278 & \\
\hline
\end{tabular}

Only randomized trials are reported. $\mathrm{NA}=$ Not available in the study.

${ }^{\text {a }}$ Blood loss is expressed in $\mathrm{ml}$.

b Value refers only to transection time.

${ }^{c}$ Blood loss is expressed in $\mathrm{ml} / \mathrm{cm}^{2}$. The number of patients transfused is expressed as a mean only in the trial by Rau et al. [9].

tomy. The role of hepatic resection was limited up to the 20th century when the Pringle maneuver was first described [1] to control bleeding mostly in emergency settings.

Due to excessive bleeding during parenchymal division, elective hepatic resection did not become popular until the late 1950s, when Tan Tung and associates [2] published the first limited series using the finger fracture technique. In this technique, the liver was crushed between the thumb and one finger, and the vessels and bile ducts successively ligated and divided.

The employment of this new technique, even in combination with pedicle clamping, could not completely prevent excessive blood loss, which still remained the limit of hepatic surgery. The finger fracture technique was not selective for the tiny vessels responsible of the weak but continuous bleeding during hepatic division. The introduction of tinier instruments such as small Kellies for blunt transection [3] allowed a more selective hemostasis, further reducing blood loss.

From this point of view, the research of the surgeon has been addressed mainly toward new instruments able to perform not only transection, but also characterized by hemostatic properties. Hepatic transection turned into a history of marriage between surgical skills and technical development. More and more studies stressed the strict relationship between transection, blood loss and unfavorable outcome [4].

\section{Technological Research}

The rationale in liver transection is to employ an instrument that can selectively eliminate parenchyma leaving vital structures intact. In other words, a resistancemodulated device, able to fragment low-resistance tissue (hepatic parenchyma) preserving fibrous (high-resistance) components such as vessels and biliary ducts, successively ligated by the surgeon. To date, no single instrument has been designed to adequately satisfy both of these tasks [5].

To achieve these targets, technological research developed using different sources of energy. In the 1980s, first the water jet dissectors appeared $[6,7]$, and later on in the 1990s, the ultrasonic dissectors $\left(\right.$ CUSA $\left.^{\circledR}\right)[8,9]$, which enabled a more selective identification and ligation of more 
tiny vessels arising from liver parenchyma. The latter instrument has been widely adopted in the last years because of its working simplicity and the fascinating way it can selectively destroy and aspirate parenchyma leaving vascular structures almost intact. One of the last devices employed since the beginning of 2000, has been the saline-linked radiofrequency sealer, in which radiofrequency energy is delivered through saline dripping from the tip of the instrument; as a result, proteins are denaturized, and coagulative necrosis occurs on the transection surface $[10,11]$. Also experiences with transection using the harmonic scalpel [12] and stapling devices [13] have quite recently been reported.

At present, evidence suggests that the gold standard in liver resection remains the clamp-crush technique under pedicle clamping. However, in the setting of technological development, cost control, sponsor disclosure and surgical skill improvement, the surgeon should be aware of both the potential of the devices available, as well as the limits featured by each one of them.

\section{Comparative Studies}

Several studies have been addressed to clarify these critical points, underlining the advantages and the drawbacks of each device.

One of the first randomized studies [8] comparing the ultrasonic dissector versus the clamp-crush technique showed that the ultrasonic dissector is more frequently associated with tumor exposure at the resection margin and with incomplete appearance of landmark hepatic veins on the cut surface. The authors did not find any difference in postoperative morbidity and blood loss, concluding that clamp-crushing technique resulted in a higher quality of hepatectomy, thus being the option of choice.

Aldrighetti et al. [12] published a relatively larger series comparing clamp-crushing with ultrasonic plus harmonic scalpel dissection. The latter resulted in longer operative time, but with a reduced blood loss (and consequently a lower transfusion rate) and with a lower rate of biliary fistula. However, the retrospective method of the study, and the relatively long period of inclusion may have biased these results against the clamp-crush technique.

A randomized study [14] comparing LigaSure ${ }^{\circledR}$ with the conventional method, demonstrated no statistical difference ( $p=0.185)$ in blood loss and mortality rate between the two groups. But, LigaSure was slightly superior in terms of transection speed, number of ties per $\mathrm{cm}^{2}$ and hemostasis time. The resulting total operating time decreased by $27 \mathrm{~min}$, and hospital stay was shortened by 2 days in the LigaSure group. The authors performed also a cost analysis which found a highly cost-effective ratio in favor of LigaSure due to shorter operative time, hospital stay and low capital cost of the disposable device. They considered $3 \mathrm{~mm}$ as the range of maximal effectiveness in sealing portal triads (without increasing the rate of biliary fistula).

A more recent randomized study [15] did not demonstrate this difference in blood loss, operating time and hospital stay, failing to find a superiority of one technique over the other. In this particular situation, the cost-effectiveness of LigaSure in the clamp-crush method was not confirmed, favoring once again the latter.

Lesurtel et al. [16], also from the cost-effectiveness point of view, provide further evidence in favor of the clamp-crush method. Their study is the only available randomized trial comparing 4 techniques at the same time (clamp-crush, CUSA, HydroJet ${ }^{\circledR}$ and Dissecting Sealer $\left.{ }^{\circledR}\right)$. The clamp-crush method was superior in transection speed, blood loss, transfusion rate, number of ligatures and transection time. However, we should keep in mind that clamp-crushing was performed only under pedicle clamping, a factor which biases these results.

As recently described in non-randomized settings [13, 17], liver transection could be also performed with the stapling technique. As reported, the technique appears to be safe and quicker. Commonly, staplers are considered to be expensive tools, but they increase only the total material cost. However, owing to decreased blood loss, transfusion rate, shorter operative time and in-hospital stay, the global cost for a hepatectomy (especially for the major ones) has considerably decreased especially in high-volume centers.

It should also be noticed that the stapling technique [18] can reduce the time of vascular control (i.e. Pringle). This fact turns out to be relevant when the resection is conducted in injured parenchyma due to prolonged chemotherapy (hepatic steatosis, sinusoidal obstruction syndrome, steatohepatitis, etc.).

\section{Fusion Technique}

The attempt to accomplish both the task of division and of hemostasis is provided by a recently introduced device, which intends to crush liver parenchyma simul- 
taneously sealing the vessels without the need to change the instrument, the so called focus-clysis or 'fusion technique' [19]. Functionally, the instrument should be compared to a Kelly, in which the surgeon can adjust the precision and depth of cutting by modulating blade pressure; parenchyma crushing exposes the tiny vessels that can be coagulated employing the harmonic technology provided in high power (1-2 mm vessels) and low power (up to $5 \mathrm{~mm}$ ). Vessels larger than $5 \mathrm{~mm}$ in diameter should be divided and ligated in a traditional fashion. It seems that the 'fusion technique' could reduce blood loss and the incidence of biliary fistula, with a cost comparable to other technologies. However, the benefits should be further demonstrated in randomized studies, which are currently lacking. In conclusion, it can be considered a new, promising and effective technology, but the clamp-crush technique should still be considered the gold standard method in liver transection.

\section{Scientific Evidence}

As part of the increasing amount of evidence, the Cochrane Collaboration in 2009 published a review on transection techniques. Among more than 800 referenc- es, 7 papers were retained which proved methodologically appropriate with respect to inclusion criteria and randomization processes $[9,16,20-23]$. The Cochrane Collaboration analyzed operative and perioperative mortality (as a primary end point). Blood losses, transfusion rate, biochemical markers of liver dysfunction, transection time and speed, and hospital stay were secondary end points.

\section{Conclusion}

In conclusion, the evidence suggests once again the superiority of Kelly-clysis among other techniques. But it must be taken into account that it is a very technically demanding method, and it strictly requires hepatic pedicle clamping. Several alternative methods have been proposed, but none of them has been demonstrated to be more effective than the others. This suggests that the use of the devices available should be assessed taking into account both the limits of each instrument as well as the skills and features of the surgeon. The best option should probably be a combined approach.

\section{References}

1 Pringle J: Notes on the arrest of hepatic hemorrhage due to trauma. Ann Surg 1908;48: 541-549.

2 Lin TY: Study on the lobectomy of the liver; a new technical suggestion on hemihepatectomy and reports of three cases of primary hepatoma treated with total left lobectomy of the liver. J Formosan Med Assoc 1958;57: 742-748.

$\$ 3$ Lin TY: A simplified technique for hepatic resection: the crush method. Ann Surg 1974; 180:285-290.

4 Kooby DA, Stockman J, Ben-Porat L, Gonen M, Jarnagin WR, Dematteo RP, Tuorto S, Wuest D, Blumgart LH, Fong Y: Influence of transfusions on perioperative and long-term outcome in patients following hepatic resection for colorectal metastases. Ann Surg 2003;237:860-869, discussion 869-870.

5 Aloia TA, Zorzi D, Abdalla EK, Vauthey JN: Two-surgeon technique for hepatic transection of the noncirrhotic liver using salinelinked cautery and ultrasonic dissection. Ann Surg 2005; 242:172-177.

6 Papachristou DN, Barters R: Resection of the liver with a water jet. Br J Surg 1982;69:9394.
7 Rau HG, Meyer G, Jauch KW, Cohnert TU, Buttler E, Schildberg FW: Liver resection with the water jet: conventional and laparoscopic surgery. Chirurg 1996;67:546-551.

-8 Takayama T, Makuuchi M, Kubota K, Harihara Y, Hui AM, Sano K, Ijichi M, Hasegawa $\mathrm{K}$ : Randomized comparison of ultrasonic vs clamp transection of the liver. Arch Surg 2001;136:922-928.

-9 Rau HG, Wichmann MW, Schinkel S, Buttler E, Pickelmann S, Schauer R, et al: Surgical techniques in hepatic resections: ultrasonic aspirator versus Jet-Cutter. A prospective randomized clinical trial. Zentralbl Chir 2001;126:586-590.

10 Sakamoto Y, Yamamoto J, Kokudo N, Seki M, Kosuge T, Yamaguchi T, et al: Bloodless liver resection using the monopolar floating ball plus ligasure diathermy: preliminary results of 16 liver resections. World J Surg 2004;28:166-172.

-11 Sturgeon C, Helton Ws, Lamba A, Chejfec G Espat NJ: Early experience employing a linear hepatic parenchyma coagulation device. J Hepatobiliary Pancreat Surg 2003;10:8186.
12 Aldrighetti L, Pulitano C, Arru M, Catena M, Finazzi R, Ferla G: 'Technological' approach versus clamp crushing technique for hepatic parenchymal transection: a comparative study. J Gastrointest Surg 2006;10:974979.

13 Kaneko H, Otsuk Y, Takagi S, Tsuchiya M, Tamura A, Shiba T: Hepatic resection using stapling devices. Am J Surg 2004;187:280284.

14 Saiura A, Yamamoto J, Koga R, Sakamoto Y, Kokudo N, Seki M, Yamaguchi T, Yamaguchi T, Muto T, Makuuchi M: Usefulness of LigaSure for liver resection: analysis by randomized clinical trial. Am J Surg 2006;192:41-45.

15 Ikeda M, Hasegawa K, Sano K, Imamura H, Beck Y, Sugawara Y, Kokudo N, Makuuchi M: The vessel sealing system (LigaSure) in hepatic resection: a randomized controlled trial. Ann Surg 2009;250:199-203.

16 Lesurtel M, Selzner M, Petrowsky H, McCormack L, Clavien PA: How should transection of the liver be performed? A prospective randomized study in 100 consecutive patients: comparing four different transection strategies. Ann Surg 2005;242: 814-822. 
-17 Schemmer P, Friess H, Hinz U, Mehrabi A, Kraus TW, Z'graggen K, Schmidt J, Uhl W, Büchler MW: Stapler hepatectomy is a safe dissection technique: analysis of 300 patients. World J Surg 2006;30:419-430.

18 Schemmer P, Bruns H, Weitz J, Schmidt J, Büchler MW: Liver transection using vascular stapler: a review. HPB (Oxford) 2008;10: 249-252.
Jagannath P, Chhabra DG, Sutariya KR, Shah RC: Fusion technique for liver transection with Kelly-clysis and harmonic technology. World J Surg 2010;34:101-105.

20 Smyrniotis V, Arkadopoulos N, Kostopanagiotou G, Farantos C, Vassiliou J, Contis J, et al: Sharp liver transection vs. clamp crushing technique in liver resections: a prospective study. Surgery 2005;137:306-311.

-21 Arita J, Hasegawa K, Kokudo N, Sano K, Sugawara Y, Makuuchi M: Randomized clinical trial of the effect of a saline-linked radiofrequency coagulator on blood loss during hepatic resection. Br J Surg 2005;92:954-959.
22 Koo BN, Kil HK, Choi JS, Kim JY, Chun DH, Hong YW: Hepatic resection by the Cavitron ultrasonic surgical aspirator increases the incidence and severity of venous air embolism. Anesth Anal 2005;101:966-970.

23 Lupo L, Gallerani A, Panzera P, Tandoi F, Di Palma G, Memeo V: Randomized clinical trial of radiofrequency-assisted vs. clampcrushing liver resection. Br J Surg 2007;94: 287-291. 